\title{
ERUPSI GIGI MOLAR PERTAMA PERMANEN BERDASARKAN LETAK GEOGRAFIS PESISIR PANTAI DAN PEGUNUNGAN DI KABUPATEN PACITAN
}

\author{
Cahya Rachmatuloh Koenela ${ }^{1}$, Agus Marjianto ${ }^{2}$, Silvia Prasetyowati ${ }^{3}$ \\ ${ }^{1,2,3}$ Poltekkes Kemenkes Surabaya Jurusan Keperawatan Gigi \\ Email : cahyakoenela@gmail.com
}

\section{Kata kunci: \\ Erupsi gigi;Molar Pertama \\ Permanen;Letak Geografis}

\begin{abstract}
ABSTRAK
Masalah dalam penelitian ini yaitu ketidaksesuaian kecepatan erupsi gigi di wilayah pesisir pantai dan pegunungan. Tujuan Penelitian ini adalah untuk mengetahui perbedaan erupsi gigi molar pertama permanen rahang atas dan bawah berdasarkan letak geografis pesisir pantai dan pegunungan Kabupaten Pacitan. Jenis penelitian yang digunakan adalah penelitian observasional analitik dengan pendekatan cross sectional. Sasaran dalam penelitian ini adalah sebagian siswa pada SD di daerah pesisir pantai yaitu Kecamatan Ngadirojo serta SD yang terletak di daerah pegunungan yaitu Kecamatan Tulakan dan dengan jumlah minimal sampel 111 anak. Metode yang digunakan untuk pengumpulan data yaitu metode observasi dan dokumentasi.Teknik analisa yang digunakan yaitu teknik analisis data chi-square dengan $\alpha=0,05$. Hasil penelitian didapatkan terdapat perbedaan waktu erupsi gigi molar pertama permanen rahang atas dan bawah berdasarkan letak geografis daerah pesisir pantai dan pegunungan Kabupaten Pacitan.

ABSTRACT

Background: The problem in this study is the mismatch of tooth eruption speed in coastal and mountainous areas. Purpose:The purpose of this study was to determine the differences in the eruption of permanent maxillary and mandibular first molars based on the geographical location of the coast and mountains of Pacitan Regency. Methods:This type of research is analytic observational research with a cross sectional approach. The target of this research is some students at elementary schools in coastal areas, namely Ngadirojo District and elementary schools located in mountainous areas, namely Tulakan and Tegalombo Districts with a minimum sample size of 111 children. The method used for data collection is the method of observation and documentation. The analysis technique used is the chi-square data analysis technique with $\alpha=$ 0.05.Result: The results showed that there was a difference in the eruption time of the upper and lower permanent first molars based on the geographical location of the coastal and mountainous areas of Pacitan Regency.
\end{abstract}

Key word:

Tooth eruption; Permanent First Molar; Geographical Position

\section{PENDAHULUAN}

Erupsi gigi merupakan rangkaian proses dari pertumbuhan dan perkembangan gigi, dimana proses yang terjadi yaitu pergerakan gigi ke arah rongga mulut secara terus menerus diawali ketika gigi masih di dalam tulang rahang dan dimulai segera setelah mahkota terbentuk. Tanda-tanda pertama dari perkembangan gigi pada embrio ditemukan di daerah anterior mandibula waktu usia 5-6 minggu. Sesudah terjadi 
tanda- tanda perkembangan gigi di daerah anterior maksila, perkembangan berlanjut kearah posterior dari kedua rahang(1).

Gigi molar pertama permanen merupakan gigi permanen pertama kali erupsi dan normalnya 6-7 tahun yang merupakan periode gigi molar pertama erupsi, gigi molar pertama merupakan gigi terbesar di antara gigi geligi yang lain dan sangat penting untuk merangsang pertumbuhan rahang di masa usia dini(1). Gigi tetap yang pertama muncul dalam rongga mulut atau erupsi adalah gigi molar petama, yang letaknya distal dari gigi molar kedua, pada usia 6 tahun. Gigi tersebut mulai terkalsifikasi pada saat bayi dilahirkan (1).

Kabupaten Pacitan merupakan Kabupaten yang terletak di Pantai Selatan Pulau Jawa dan memiliki karakteristik wilayah perbukitan (85\% dari luas wilayah) dan merupakan kawasan ekokarst. Adapun wilayah administrasi Kabupaten Pacitan yaitu memiliki 12 Kecamatan, 5 Kelurahan dan 166 Desa (total 171 Desa/Kelurahan) dengan letak geografis berada antara $110^{\circ} 55^{\prime}-111^{\circ} 25^{\prime}$ Bujur Timur dan $7^{\circ} 55^{\prime}-8^{\circ} 17^{\prime}$ Lintang Selatan (2).

Berada di Laut Selatan, maka potensi yang bisa diambil dari laut pun sangat banyak. Seperti diketahui, bahwa luas wilayah laut Kabupaten Pacitan mencapai 7.636 mil persegi dengan 12 pantai merupakan daerah untuk pendaratan ikan oleh nelayan. Sehingga potensi wilayah laut tersebut sebesar kurang lebih 84.4330 ton pertahun, dan ikan lobster mempunyai daya jual yang cukup tinggi di Pacitan. Tangkapan ikan dan lobster yang dihasilkan, hasilnya dikonsumsi penduduk dan dijual ke luar daerah (2).

Perbedaan jenis komoditi ini menyebabkan perbedaan jenis dan jumlah pangan yang biasa dikonsumsi sehari-hari. Masyarakat di daerah pantai yang sebagian besar adalah nelayan cenderung mengkonsumsi makanan sumber protein hewani yang berasal dari laut, sedangkan masyarakat di daerah perbukitan (dataran tinggi) yang sebagian besar adalah petani sawah atau ladang cenderung mengkonsumsi makanan sumber protein nabati (3).

Ikan merupakan sumber protein dan kalsium dengan kualitas tinggi. Kandungan gizi ikan ini sangat bagus untuk tulang dan gigi. Makanan dengan kualitas dan konsentrasi protein dan kalsium yang tinggi mempunyai hubungan linier dengan pertumbuhan dan perkembangan tulang dan gigi. Hal ini disebabkan protein merupakan makanan yang mengandung banyak asam amino sebagai unsur pembangun struktur jaringan tubuh, sedangkan kalsium merupakan mineral penting yang berperan dalam seluruh proses metabolisme tulang dan gigi $(4,5)$.

Kalsium merupakan zat gizi mikro yang dibutuhkan oleh tubuh dan mineral yang paling banyak terdapat dalam tubuh, yaitu $1,5-2 \%$ dari berat badan orang dewasa atau kurang lebih sebanyak $1 \mathrm{~kg}$. Hampir seluruh kalsium ada dalam tulang yang berperan sentral dalam strukur dan kekuatan tulang dan gigi.Fungsi kalsium antara lain untuk pembentukan tulang dan gigi, berperan dalam pertumbuhan dan sebagai faktor pembantu dan pengatur biokimia dalam tubuh (6).

Gizi mikro salah satunya kalsium membantu pembentukan dan pemeliharaan tulang dan gigi. Anak-anak memerlukan kalsium untuk pembentukan tulang dan gigi mereka, kekurangan kalsium dapat mengakibatkan pertumbuhan tulang anak tidak 
sempurna, orang dewasa memerlukan kalsium terus menerus untuk meremajakan sistem tulang dan giginya (6).

Tumbuh kembang gigi terjadi sejak janin masih dalam kandungan ibu hingga beberapa tahun setelah kelahiran dan meliputi fase pertumbuhan, kalsifikasi, serta erupsi gigi. Kalsium merupakan salah satu faktor penting bagi tumbuh kembang gigi geligi yang akan mempengaruhi keadaan dan waktu erupsi gigi (6).

Penelitian Rahmawati (2014) di Kecamatan Kasihan Bantul,DIY yang merupakan daerah pegunungan sebagian besar penduduk bekerja sebagai petani, dan mengkonsumsi sumber makanan protein nabati. Hasilnya di dapatkan 30 siswa usia 67 tahun status gizi baik, yang sudah erupsi 28 (80\%) dan yang belum erupsi $2(20 \%)$. Tahapan erupsi gigi yang sudah erupsi sempurna $75 \%$, erupsi sebagian $21,7 \%$ dan belum erupsi 3,3\%(7).

Penelitian Lantu., dkk (2015) di Manado yang merupakan daerah pesisir pantai. Hasilnya dari 49 responden usia 6-7 tahun didapat $53 \%$ belum mengalami erupsi gigi dan $47 \%$ sudah mengalami erupsi gigi(8). Hal ini menandakan bahwa di daerah pesisir pantai mengalami perlambatan erupsi gigi, tidak sesuai dengan hasil penelitian yang telah di kemukakan oleh Bozini dkk., 2011 cit. Aryati 2014. Penelitian ini bertujuan untuk Untuk mengetahui perbedaan waktu erupsi gigi berdasarkan letak geografis pesisir pantai dan pegunungan Kabupaten Pacitan

\section{METODE}

Penelitian ini telah melalui persetujuan komisi etik penelitian kesehatan Poltekkes Kemenkes Surabaya No.EA/0112/KEPK-Poltekkes_Sby/V/2019. Jenis penelitian yang dilakukan dalam penelitian ini adalah penelitian observasional analitik dengan pendekatan cross sectional. Populasi dalam penelitian ini Seluruh siswa pada SD di daerah pesisir pantai yaitu Kecamatan Ngadirojo serta SD yang terletak di daerah pegunungan yaitu Kecamatan Tulakan, Kabupaten Pacitan dengan rentang usia 6-7 tahun. Sampel dalam penelitian ini sebagian siswa pada SD di daerah pesisir pantai yaitu Kecamatan Ngadirojo serta SD yang terletak di daerah pegunungan yaitu Kecamatan Tulakan, Kabupaten Pacitan dengan rentang usia 6-7 tahun. Dalam mencari besar sampel penelitian ini menggunakan rumus jumlah perhitungan sampel minimal rerata untuk 2 populasi (mean)jumlah minimal sampel untuk didaerah pesisir pantai yaitu 111 anak serta untuk pegunungan sebanyak 111 anak.

Metode pengumpulan data Metode yang digunakan untuk pengumpulan data yaitu metode observasi dan dokumentasi. Pengumpulan data dalam penelitian inianak menyerahkan informed consent yang telah diisi oleh orangtua atau wali siswa, anak dikelompokkan berdasarkan jenis kelamin, Anak dipersilahkan duduk, peneliti mengisi data anak yang akan diperiksa pada lembar observasi yang terdiri dari nama, tempat tanggal lahir, jenis kelamin dan alamat. Peneliti melakukan pemeriksaan oral dengan menggunakan kaca mulut dan juga senter untuk melihat gigi molar satu pemanen rahang atas dan rahang bawah yang telah erupsi dan mencatatnya dalam lembar observasi. Tahapan munculnya gigi ke dalam rongga mulut dapat diklasifikasikan menjadi empat tahap yaitu $0.00=$ gigi belum terlihat di dalam rongga 
mulut, $0.25=$ cusp terlihat $0.50=$ setengah mahkota terlihat $1.00=$ erupsi sempurna ${ }^{(9)}$.Peneliti mengambil dokumentasi.

\section{HASIL DAN PEMBAHASAN}

\section{Karakteristik Penelitian di pegunungan}

Penelitian yang dilakukan daerah pegunungan Kecamatan Tulakan sebanyak 117 siswa yang terdiri dari 59 siswa laki-laki dan 58 siswa perempuan. Perolehan data diambil dari SDN Kalikuning 1, SDN Bungur 1, SDN Gasang 1 dan MIN 1 Pacitan, diperoleh data umur untuk daerah pegunungan Kecamatan Tulakan sebanyak 72 siswa berumur 6 tahun dan 45 siswa berumur 7 tahun. Perolehan data diambil dari SDN Kalikuning 1, SDN Bungur 1, SDN Gasang 1 dan MIN 1 Pacitan.

Tabel 1 Karakteristik sampel di pesisir

\begin{tabular}{ccc}
\hline \multicolumn{2}{c}{ Variabel Karakteristik } & N \\
\hline Usia & 6 Tahun & 72 \\
& 7 Tahun & 45 \\
\multirow{2}{*}{ Jenis Kelamin } & Laki-laki & 59 \\
& Perempuan & 58 \\
\hline
\end{tabular}

\section{Karakteristik penelitian di pesisir pantai}

Karakteristik daerah pesisir pantai Kecamatan Ngadirojo sebanyak 116 siswa yang terdiri dari 66 siswa laki-laki dan 50 siswa perempuan. Perolehan data diambil dari SDN Sidomulyo 4, SDN Ngadirojo 1, dan SD Islam Nurul Yaqin Pacitan, diperoleh data umur untuk daerah pegunungan Kecamatan Tulakan sebanyak 74 siswa berumur 6 tahun dan 42 siswa berumur 7 tahun. Perolehan data diambil dari SDN Sidomulyo 4, SDN Ngadirojo 1, dan SD Islam Nurul Yaqin Pacitan.

Tabel 2 Karakteristik sampel di pesisir pantai

\begin{tabular}{clc}
\hline \multicolumn{2}{c}{ Variabel Karakteristik } & N \\
\hline Usia & 6 Tahun & 74 \\
& 7 Tahun & 42 \\
\multirow{2}{*}{ Jenis Kelamin } & Laki-laki & 66 \\
& Perempuan & 50 \\
\hline
\end{tabular}




\section{Hasil pengumpulan data}

Tabel 3 hasil pengumpulan data di pegunungan \pm standar deviasi.

\begin{tabular}{llllll}
\hline gigi & \multicolumn{4}{c}{ Erupsi Gigi } & N \\
\cline { 2 - 5 } & $\begin{array}{l}\text { Cusp } \\
\text { belum } \\
\text { terlihat }\end{array}$ & $\begin{array}{l}\text { Cusp } \\
\text { terlihat }\end{array}$ & $\begin{array}{l}\text { Setengah } \\
\text { mahkota } \\
\text { terlihat }\end{array}$ & $\begin{array}{l}\text { Erupsi } \\
\text { sempurna }\end{array}$ & \\
\hline $\mathbf{1 6}$ & $14 \pm$ & $31 \pm$ & $49 \pm$ & $23 \pm$ & 117 \\
& 0,256 & 0,445 & 0,500 & 0,444 & \\
\hline $\mathbf{2 6}$ & $10 \pm$ & $25 \pm$ & $52 \pm$ & $30 \pm$ & 117 \\
& 0,402 & 0,498 & 0,459 & 0,476 & \\
\hline $\mathbf{3 6}$ & $8 \pm$ & $20 \pm$ & $51 \pm$ & $38 \pm$ & 117 \\
& 0,420 & 0,430 & 0,476 & 0,465 & \\
\hline $\mathbf{4 6}$ & $6 \pm$ & $25 \pm$ & $53 \pm$ & $33 \pm$ & 117 \\
& 0,320 & 0,315 & 0,497 & 0,464 & \\
\hline
\end{tabular}

Berdasarkan tabel 3 didapatkan hasil pada rahang atas daerah pegunungan untuk elemen gigi 16 sebanyak $14 \pm 0,256$ cusp belum terlihat, $31 \pm 0,445$ siswa cusp terlihat, $49 \pm 0,500$ siswa setengah mahkota terlihat dan $23 \pm 0,444$ siswa sudah mengalami erupsi gigi sempurna. Pada gigi 26 sebanyak $10 \pm 0,402$ cusp belum terlihat, 25 \pm 0,498 siswa cusp terlihat, $52 \pm 0,459$ siswa setengah mahkota terlihat dan $30 \pm 0,476$ siswa sudah mengalami erupsi sempurna.

Pada rahang bawah daerah pegunungan untuk elemen gigi 36 sebanyak $8 \pm 0,420$ cusp belum terlihat, $20 \pm 0,430$ siswa cusp terlihat, $51 \pm 0,476$ siswa setengah mahkota terlihat, $38 \pm 0,465$ siswa sudah mengalami erupsi sempurna. Gigi 46 sebanyak $6 \pm$ 0,320 cusp belum terlihat, $25 \pm 0,315$ siswa cusp terlihat, $53 \pm 0,497$ siswa setengah mahkota terlihat dan $33 \pm 0,464$ siswa sudah erupsi sempurna.

Tabel 4 hasil pengumpulan data di pesisir pantait standar deviasi.

\begin{tabular}{|c|c|c|c|c|c|}
\hline \multirow[t]{2}{*}{ gigi } & \multicolumn{4}{|c|}{ Erupsi Gigi } & $\mathbf{N}$ \\
\hline & $\begin{array}{l}\text { Cusp } \\
\text { belum } \\
\text { terlihat }\end{array}$ & $\begin{array}{l}\text { Cusp } \\
\text { terlihat }\end{array}$ & $\begin{array}{l}\text { Setengah } \\
\text { mahkota } \\
\text { terlihat }\end{array}$ & $\begin{array}{l}\text { Erupsi } \\
\text { sempurna }\end{array}$ & \\
\hline 16 & $\begin{array}{l}1 \pm \\
0,442\end{array}$ & $\begin{array}{l}11 \pm \\
0,597\end{array}$ & $\begin{array}{l}40 \pm \\
0,653\end{array}$ & $64 \pm 0,597$ & 116 \\
\hline 26 & $\begin{array}{l}0 \pm \\
0,340\end{array}$ & $\begin{array}{l}6 \pm \\
0,451\end{array}$ & $\begin{array}{l}39 \pm \\
0,735\end{array}$ & $71 \pm 0,575$ & 116 \\
\hline 36 & $\begin{array}{l}0 \pm \\
0,294\end{array}$ & $\begin{array}{l}6 \pm \\
0,475\end{array}$ & $\begin{array}{l}26 \pm \\
0,655\end{array}$ & $84 \pm 0,664$ & 116 \\
\hline 46 & $\begin{array}{l}0 \pm \\
0,344\end{array}$ & $\begin{array}{l}3 \pm \\
0,405\end{array}$ & $\begin{array}{l}39 \pm \\
0,626\end{array}$ & $74 \pm 0,668$ & 116 \\
\hline
\end{tabular}

Berdasarkan tabel 4 didapatkan hasil pada daerah pesisir pantai untuk elemen gigi 16 sebanyak $1 \pm 0,442$ siswa cusp belum terlihat, $11 \pm 0,597$ siswa cusp terlihat, 40 $\pm 0,653$ siswa setengah mahkota terlihat dan $64 \pm 0,597$ siswa sudah mengalami erupsi gigi sempurna. Pada gigi 26 sebanyak $0 \pm 340$ siswa cusp belum terlihat, $6 \pm 0,451$ siswa cusp terlihat, $39 \pm 0,735$ siswa setengah mahkota terlihat dan $71 \pm 0,575$ siswa sudah mengalami erupsi sempurna.

Hasil pada daerah pesisir pantai untuk elemen gigi 36 cusp belum terlihat $0 \pm 0,294$, $6 \pm 0,475$ siswa cusp terlihat, $26 \pm 0,655$ siswa setengah mahkota terlihat, $84 \pm 0,664$ 
siswa sudah mengalami erupsi sempurna. Gigi 46 cusp belum terlihat $0 \pm 0,344,3 \pm$ 0,405 siswa cusp terlihat, $39 \pm 0,626$ siswa setengah mahkota terlihat dan $74 \pm 0,668$ siswa sudah erupsi sempurna.

\section{Hasil uji Chi Square \pm standar deviasi}

Tabel 5 hasil uji Chi Square \pm standar deviasi

\begin{tabular}{|c|c|c|c|c|c|}
\hline \multirow{2}{*}{$\begin{array}{c}\text { Letak } \\
\text { Geografis }\end{array}$} & \multicolumn{4}{|c|}{ Erupsi gigi 16} & \multirow[t]{2}{*}{$\boldsymbol{P}$} \\
\hline & 0.00 & 0.25 & 0.50 & 1.00 & \\
\hline $\begin{array}{l}\text { Pegunun } \\
\text { gan }\end{array}$ & $\begin{array}{l}14 \pm \\
0,256\end{array}$ & $\begin{array}{l}31 \pm \\
0,445\end{array}$ & $\begin{array}{l}49 \pm \\
0,500\end{array}$ & $\begin{array}{l}23 \pm \\
0,444\end{array}$ & 0,000 \\
\hline $\begin{array}{l}\text { Pesisir } \\
\text { pantai }\end{array}$ & $\begin{array}{l}1 \pm \\
0,442\end{array}$ & $\begin{array}{l}11 \pm \\
0,597\end{array}$ & $\begin{array}{l}40 \pm \\
0,653\end{array}$ & $\begin{array}{l}64 \pm \\
0,597\end{array}$ & \\
\hline \multirow{2}{*}{$\begin{array}{c}\text { Letak } \\
\text { Geografis }\end{array}$} & \multicolumn{4}{|c|}{ Erupsi gigi 26} & $\bar{P}$ \\
\hline & 0,00 & 0.25 & 0.50 & 1.00 & \\
\hline \multirow{2}{*}{$\begin{array}{l}\text { Pegunun } \\
\text { gan } \\
\text { Pesisir } \\
\text { pantai }\end{array}$} & $\begin{array}{l}10 \pm \\
0,402\end{array}$ & $\begin{array}{l}25 \pm \\
0,498\end{array}$ & $\begin{array}{l}52 \pm \\
0,459\end{array}$ & $\begin{array}{l}30 \pm \\
0,476\end{array}$ & \multirow[t]{2}{*}{0,000} \\
\hline & $\begin{array}{l}0 \pm \\
0,340\end{array}$ & $\begin{array}{l}6 \pm \\
0,451\end{array}$ & $\begin{array}{l}39 \pm \\
0,735\end{array}$ & $\begin{array}{l}71 \pm \\
0,575\end{array}$ & \\
\hline \multirow{2}{*}{$\begin{array}{c}\text { Letak } \\
\text { Geografis }\end{array}$} & \multicolumn{4}{|c|}{ Erupsi gigi 36} & \multirow[t]{2}{*}{$\bar{P}$} \\
\hline & 0.00 & 0.25 & 0.50 & 1.00 & \\
\hline \multirow{2}{*}{$\begin{array}{l}\text { Pegunun } \\
\text { gan } \\
\text { Pesisir } \\
\text { pantai }\end{array}$} & $\begin{array}{l}8 \pm \\
0,420\end{array}$ & $\begin{array}{l}20 \pm \\
0,430\end{array}$ & $\begin{array}{l}51 \pm \\
0,475\end{array}$ & $\begin{array}{l}38 \pm \\
0,465\end{array}$ & \multirow[t]{2}{*}{0,000} \\
\hline & $\begin{array}{l}0 \pm \\
0,294\end{array}$ & $\begin{array}{l}6 \pm \\
0,475\end{array}$ & $\begin{array}{l}26 \pm \\
0,655\end{array}$ & $\begin{array}{l}84 \pm \\
0,664\end{array}$ & \\
\hline \multirow{2}{*}{$\begin{array}{c}\text { Letak } \\
\text { Geografis }\end{array}$} & \multicolumn{4}{|c|}{ Erupsi gigi 46} & $P$ \\
\hline & 0.00 & 0.25 & 0.50 & 1.00 & \\
\hline \multirow{2}{*}{$\begin{array}{l}\text { Pegunun } \\
\text { gan } \\
\text { Pesisir } \\
\text { pantai }\end{array}$} & $\begin{array}{l}6 \pm \\
0,320\end{array}$ & $\begin{array}{l}25 \pm \\
0,315\end{array}$ & $\begin{array}{l}53 \pm \\
0.497\end{array}$ & $\begin{array}{l}3 \pm \\
0,464\end{array}$ & \multirow[t]{2}{*}{0,000} \\
\hline & $\begin{array}{l}0 \pm \\
0,344\end{array}$ & $\begin{array}{l}3 \pm \\
0,405\end{array}$ & $\begin{array}{l}39 \pm \\
0,626\end{array}$ & $\begin{array}{l}74 \pm \\
0,668\end{array}$ & \\
\hline
\end{tabular}

Berdasarkan tabel diatas bahwa hasil perhitungan yang diperoleh nilai $\rho$ (signifikan) kurang dari nilai $\alpha=0.05(0,000<0,05)$ Kesimpulan yang diperoleh hasil analisis data dengan menggunakan uji Chi-Squarebahwa H1 diterima yang berarti terdapat perbedaan.

\section{PEMBAHASAN}

Hasil analisis data bahwa $\mathrm{H} 1$ diterima yang berarti terdapat perbedaan erupsi gigi molar pertama permanen berdasarkan letak geografis daerah pesisir pantai dan pegunungan Kabupaten Pacitan.

Perbedaan yang didapat ini dipengaruhi oleh letak geografis. Letak geografis mempengaruhi jenis makanan masyarakat pada setiap daerah. di lihat dari keadaan geografi dan sumber daya perairan, masyarakat di daerah pantai sebagian besar adalah nelayan yang banyak mengkonsumsi makanan sumber protein hewani yang berasal dari laut seperti ikan, sedangkan masyarakat didaerah pegunungan sebagian besar adalah petani sawah atau ladang sehingga lebih banyak mengkonsumsi makanan sumber karbohidrat dan protein nabati. Bahan pangan sumber protein pada daerah pantai dapat terpenuhi setiap hari dengan baik, hal ini dikarenakan hasil laut yang juga dikonsumsi oleh keluarga sendiri ${ }^{(3)}$

Hasil laut yang salah satunya yaitu ikan merupakan sumber protein dan kalsium dengan kualitas tinggi. Kandungan gizi ikan ini sangat bagus untuk tulang dan gigi. Makanan dengan kualitas dan konsentrasi protein dan kalsium yang tinggi 
mempunyai hubungan linier dengan pertumbuhan dan perkembangan tulang dan gigi, Hal ini disebabkan protein merupakan makanan yang mengandung banyak asam amino sebagai unsur pembangun struktur jaringan tubuh, sedangkan kalsium merupakan mineral penting yang berperan dalam seluruh proses metabolisme tulang dan gigi ${ }^{(4,5)}$.

Pada daerah punggung bukit atau pegunungan, bahan pangan sumber protein yang berasal dari ikan tidak tersedia setiap hari, kalaupun ada setiap hari jumlahnya jauh lebih sedikit dibandingkan dengan daerah pantai dan harganya pun tidak murah. Dengan demikian kebutuhan protein keluarga di daerah punggung bukit akan kurang untuk memenuhi kebutuhan tubuh.

Ketersediaan akan sumber protein yag berasal dari ikan menjadikan perbedaan juga. Masyarakat di daerah punggung bukit rata-rata mengkonsumsi ikan yang sudah diolah lanjutan seperti ikan tongkol panggang dan ikan pindang, sedangkan masyarakat di wilayah pantai lebih bayak mengkonsumsi ikan laut segar dan hasil laut lannya berupa udang, cumi-cumi, atau kepiting. Selain itu konsumsi sumber protein nabati berupa tahu/tempe lebih dominan di konsumsi oleh masyarakat di wilayah punggung bukit ${ }^{(9)}$.

Kesimpulan yang bisa diambil bahwa letak geografis mempengaruhi kecepatan waktu erupsi gigi, erupsi gigi pada anak yang tinggal di daerah letak geografis pesisir pantai lebih cepat daripada daerah pegunungan, hal ini disebabkan karena perbedaan pola konsumsi makanan.

Pada daerah pesisir pantai kebanyakan penduduknya mengkonsumsi ikan yang kaya akan protein sehingga konsentrasi protein dan kalsium yang tinggi pada ikan mempunyai hubungan linier dengan pertumbuhan dan perkembangan tulang dan gigi sehingga kemungkinan akan mempercepat erupsi gigi, diperkuat dengan penelitian yang dilakukan oleh Salim (2014) yang menyatakan bahwa dari 30 responden tingkat kecukupan protein di Kecamatan Ngadirojo cukup 14 kurang 10 dan sangat kurang 6, tingkat kecukupan kalsium di Ngadirojo cukup 27 dan kurang 3. ${ }^{(10)}$

Daerah pegunungan yang kebanyakan mengkonsumsi makanan nabati seperti sayursayuran, akan menyebabkan asupan protein dan kalsium yang diterima lebih rendah sehingga kemungkinan erupsi gigi akan lebih lambat, diperkuat dengan penelitian yang dilakukan oleh Salim (2014) yang menyatakan bahwa dari 32 responden di Kecamatan Tulakan didapatkan tingkat kecukupan protein ditulakan cukup 9 kurang 10 dan sangat kurang 13 , tingkat kecukupan kalsium cukup 4 kurang $28^{(10)}$.

Penelitian yang dilakukan oleh Fitriyanti (2014) yang menyatakan bahwa sebagian besar subyek di daerah pesisir pola konsumsi ikannya termasuk kedalam kategori sering sekali dengan presentase $42 \%$, sering $24 \%$, kadang $17 \%$, jarang dan jarang sekali $0 \%$, Hal ini disebabkan karena perbedaan frekuensi pola konsumsi makanan di suatu daerah dapat dipengaruhi oleh persediaan bahan pangan, sedangkan tersedianya sumber bahan pangan tergantung dengan faktor-faktor seperti letak geografi, iklim, sumber daya perairan, jenis pekerjaan dan transportasi. ${ }^{(1)}$

Di daerah pesisir rata-rata penduduk bekerja sebagai nelayan sehingga ketersediaan ikan di daerah pesisir dalam jumlah banyak dan ikan yang didapatkan relative segar. 
Umumnya keluarga nelayan mengkonsumsi ikan yang berasal dari hasil melaut. Sedangkan pada daerah pegunungan pola konsumsi ikan termasuk dalam kategori sering sekali sebanyak $0 \%$, sering $20 \%$, kadang-kadang dengan presentase $70 \%$, jarang $10 \%$, jarang sekali $0 \%$, hal ini disebabkan karena masyarakat di daerah pegunungan sebagian besar mempunyai mata pencaharian sebagai petani.

Letak geografis daerah pegunungan yang jauh dari pantai mempengaruhi ketersediaan ikan, selain itu karena letak daerah pegunungan yang jauh dari pasar ikan mempengaruhi lamanya waktu transportasi sehingga jumlah ikan yang terdistribusi ke daerah pegunungan sedikit. Terbatasnya jumlah ikan di daerah pegunungan mempengaruhi pola konsumsi masyarakat,akibatnya terdapat perbedaan keadaan rongga mulut pada anak dengan konsumsi ikan dan tidak ${ }^{(12)}$.

Faktor lain yang mempengaruhi erupsi gigi yaitu umur. Berdasarkan data bahwa siswa yang berumur 6 tahun lebih banyak daripada siswa yang berumur 7 tahun baik di daerah pegunungan maupun pesisir pantai. Hal ini sejalan dengan laporan penelitian yang dilakukan oleh Indriyanti dkk., (2006) tentang pola erupsi gigi permanen ditinjau dari usia kronologis pada anak usia 6 sampai 12 tahundi SDN Sirnasari Desa Ciptasari Kecamatan Pamulihan Kabupaten Sumedang bahwa waktu erupsi gigi rahang bawah, gigi molar pertama erupsi pada umur rata-rata 6,00 tahun $^{(13)}$.

Tetapi berdasarkan penelitian Rahmawati (2014) di Kecamatan Kasihan Bantul,DIY yang merupakan daerah pegunungan sebagian besar penduduk bekerja sebagai petani, dan mengkonsumsi sumber makanan protein nabati. Hasilnya di dapatkan 30 siswa usia 6-7 tahun status gizi baik, yang sudah erupsi 28 (80\%) dan yang belum erupsi 2 (20\%). Tahapan erupsi gigi yang sudah erupsi sempurna $75 \%$, erupsi sebagian $21,7 \%$ dan belum erupsi $3,3 \%{ }^{(7)}$.

Penelitian Lantu., dkk (2015) di Manado yang merupakan daerah pesisir pantai. Hasilnya dari 49 responden usia 6-7 tahun didapat $53 \%$ belum mengalami erupsi gigi dan $47 \%$ gigi sudah mengalami erupsi, hal ini menandakan bahwa di daerah pesisir pantai mengalami perlambatan erupsi gigi, tidak sesuai dengan hasil penelitan yang telah di lakukan oleh Bozini dkk., 2011 cit. Aryati 2014. ${ }^{(4,5,7)}$

Berdasarkan penelitian yang dilakukan oleh Hamidah., dkk (2016) menunjukkan hasil yang berbanding terbalik, bahwa bahan makanan sumber protein yang dikonsumsi keluarga di wilayah dataran tinggi lebih beragam dibandingkan dengan daerah dataran rendah dan dearah pantai. Walaupun tinggal di daerah dataran tinggi, tetapi masyarakat ternyata juga mengkonsumsi bahan makanan sumber protein dari hasil laut seperti udang, kerang, cumi-cumi dan ikan asin, serta ikan tawar, selain mengkonsumsi tahu tempe dan hasil ternak kecil seperti ayam serta telur ayam.

Pembangunan infrastruktur diwilayah tersebut yang baik sehingga memudahkan keluarga memperoleh berbagai jenis bahan makanan yang dibutuhkan. Ketersediaan sarana transportasi yang baik ketersediaan bahan-bahan makanan laut cukup tinggi di wilayah tersebut, baik melalui pedagang keliling, warung, atau pasar ${ }^{(12)}$.

Hasil penelitian ini juga sejalan dengan penelitian yang dilakukan oleh Pangerapan., dkk (2018) di dusun Rarumis Desa Karor Kecamatan Lembean Timuryang 
menyatakan bahwa walaupun masyarakat tinggal di pesisir pantai, tetapi pekerjaan mereka sebagian besar adalah bertani, dan ada juga sebagai buruh tani, nelayan hanya pekerjaan sampingan. Dilihat dari pandangan tersebut masyarakat yang berada di pesisir pantai pendapatan tidak menetap sehingga mempengaruhi konsumsi. Aktivitas ekonomi penduduk di dominasi dengan sektor pertanian dan perkebunan, sebagian besar lahan yang ada digunakan oleh petani untuk melakukan kegiatan usaha tani seperti menanam rica, jagung, kelapa dan cengkih, kacang tanah, pisang yang dijadikan sebagai sumber pendapatan oleh masyarakat pesisir pantai ${ }^{(14)}$.

Berdasarkan penjelasan diatas dapat disimpulkan bahwa pola konsumsi tidak hanya dipengaruhi oleh keadaan geografisnya saja tapi juga dipengaruhi oleh sosial ekonomi dan juga jarak tempuh antar daerah.

Berdasarkan hasil analisis data juga di dapatkan kesimpulan bahwa waktu erupsi gigi molar pertama rahang bawah baik di pesisir maupun di pegunungan lebih cepat dibandingkan gigi molar pertama rahang atas. Sesuai dengan teori gigi tetap yang pertama muncul dalam rongga mulut atau erupsi adalah gigi molar petama, yang letaknya distal dari gigi molar kedua, pada usia 6 tahun. Gigi tersebut mulai ter kalsifikasi pada saat bayi dilahirkan ${ }^{(1)}$.

Daerah pesisir pantai hampir seluruh siswa sudah mengalami erupsi gigi hanya 1 siswa saja yaitu pada gigi rahang atas sebelah kanan yang belum mengalami erupsi gigi dari 116 siswa dan sebanyak 64 pada gigi rahang atas sebelah kanan, 71 pada gigi rahang atas sebelah kiri, 84 pada gigi rahang bawah kiri serta 74 pada gigi rahang bawah kanan sudah erupsi sempurna, di daerah pegunungan didapatkan 38 siswa belum mengalami erupsi gigi dari 117 siswa dan sebanyak 23 pada gigi rahang atas sebelah kanan, 30 pada gigi rahang atas sebelah kiri, 38 gigi rahang bawah sebelah kiri dan 33 gigi rahang bawah sebelah kanan sudah mengalami erupsi sempurna.

Berdasarkan pernyataan tersebut, dapat disimpulkan bahwa untuk erupsi gigi molar pertama permanen rahang atas dan bawah rata-rata sudah erupsi, yang membedakan hanya tingkatan erupsi. Terjadi perbedaan waktu erupsi gigi yang signifikan antara daerah pegunungan dan pesisir pantai. Terjadinya perbedaan waktu erupsi gigi karena perbedaan letak geografis yaitu faktor lingkungan, faktor pola konsumsi makanan yang berbeda, pada daerah pesisir pantai konsumsi makanan lebih banyak asupan protein hewani seperti ikan dan hasil laut lainnya sedangkan di daerah pegunungan lebih banyak asupan protein nabati.

Jenis kelamin merupakan salah satu faktor lain yang mempengaruhi erupsi gigi. Hasil penelitian yang dilakukan oleh Marjianto, dkk (2019) tentang erupsi gigi permanen berdasarkan usia kronologis dan jenis kelamin pada anak usia 6-12 tahun di Madura menujukkan bahwa gigi tetap pada jenis kelamin perempuan secara kronologis pada usia 6-12 tahun erupsi lebih awal daripada anak dengan jenis kelamin laki-laki. Erupsi paling awal terjadi pada gigi kaninus mandibula permanen anak perempuan ${ }^{(15)}$.

Berdasarkan pemaparan diatas penulis dapat menarik kesimpulan bahwa terjadinya perbedaan erupsi gigi di daerah pesisir pantai dan pegunungan tidak hanya dipengaruhi oleh faktor geografis. Faktor geografis hanya menjadi satu dari sekian banyak faktor yang mempengaruhi erupsi gigi. Banyak faktor lain yang 
mempengaruhi seperti status gizi, umur, jenis kelamin, sosial ekonomi, genetik, ras dan lainnya.

\section{KESIMPULAN}

Berdasarkan penelitian hasil analisis data dengan menggunakan uji Chi-Square didapatkan kesimpulan terdapat perbedaan kecepatan waktu erupsi gigi molar pertama permanen berdasarkan letak geografis bahwa kecepatan waktu erupsi di daerah pesisir pantai lebih awal dari pegunungan di Kabupaten Pacitan. Disarankan untuk dapat digunakan sebagai acuan untuk dapat dikembangkan pada penelitian selanjutnya dengan menambahkan variabel lain yang diteliti yaitu dengan menambahkan gizi mikro atau makro sebagai faktor pertumbuhan dan perkembangan gigi, jenis kelamin, status ekonomi, keturunan serta faktor lokal yang mempengaruhi erupsi gigi.

\section{DAFTAR PUSTAKA}

1. Itjiningsih W H.2014. Anatomi Gigi. Jakarta: EGC. Hal: 293-334.

2. Pramudita R.2017. Statistik Daerah Kabupaten Pacitan. Pacitan: BPS Kabupaten Pacitan. Hal: 1-30.

3. Auliya C, Woro O, Budiono I. 2015. Profil Status Gizi Balita Ditinjau Dari Topografi Wilayah Tempat Tinggal (Studi di Wilayah Pantai Dan Wilayah Punggung Bukit Kabupaten Jepara). Unnes Journal of Public Health. 4(2): 112-115.

4. Bozzini E, Graciela C, 2011. Mineral Density and Bone Strength From Mandible of Chronically Protein Restricted Rat. Acto Odontol Latinoam. 24( 3): 22.

5. Aryati E, Darmayanti A. 2014. Manfaat Ikan Teri Segar terhadap Pertumbuhan Tulang dan Gigi. Odonto Dental Journal. 1(2): 52-56.

6. Sita A, Sulistyani. 2014. Pengaruh Kalsium Terhadap Tumbuh Kembang Gigi Geligi. J.K.G Unej. 7(3): 40-44.

7. Rahmawati A, Hastami R, Medawati A. 2014. Hubungan Antara Status Gizi dengan Status Erupsi Gigi Molar Permanen Mandibula. IDJ. 3(1):17-21.

8. Lantu V, Kawengian S, Wowor V. 2015. Hubungan Status Gizi dengan Erupsi Gigi Permanen Siswa SDN 70 Manado. Jurnal e-Gigi(eG). 3(1): 189-196.

9. Kutesa A, Nkamba E, Muwazi L, Buwembo W, Rwenyonyi C.2013. Weight, Height and Eruption Times of Permanent Teeth of Children Aged 4-15 Years in Kampala, Uganda. BMC Oral Health.13(1): 1-8.

10. Salim L, Sumarni S. 2014. Diversifikasi Konsumsi Masyarakat Berdasarkan Menu Seimbang an Skor Pola Pangan Harapan pada Keluarga Balita di Kabupaten Pacitan. Journal of public health. 4(1): 14-20.

11. Fitriyanti A, Susilowati A, Darjono U. 2014. Perbedaan pola konsumsi ikan dan status kesehatan gigi dan mulut pada anak sekolah dasar 7-12 tahun di daerah pesisir dan non pesisir Kabupaten Jepara. Odonto Dental Journal. 1(1): 6-10.

12. Hamidah S, Sartono A, Kusuma H. 2017. Perbedaan pola konsumsi bahan makanan sumber potein di daerah pantai, dataran rendah dan dataran tinggi. Jurnal gizi. 6(1): 21-28.

13. Indriyanti R, Pertiwi A, Sasmita S. 2006. Pola Erupsi Gigi Permanen Ditinjau dari Usia Kronologis Pada Anak Usia 6 sampai 12 Tahun di Kabupaten Sumedang. Bandung: Fakultas Kedokteran Gigi Universitas Padjajaran. Laporan Penelitian. 4(138): 23-34. 
14. Pangerapan M, Esry L, Tangkere E. 2018. Analisis pendapatan dan konsumsi masyarakat pesisir pantai. Agri-sosio ekonomi UNSRAT. 14(1): 73-80.

15. Marjianto A., Sylvia Mieke., Wahluyo Soegeng. 2019.Permanent tooth eruption based on chronological age and gender in 6-12-year old children on Madura. Dental Journal. 52(2): 100-104. http://dx.doi.org/10.20473/j.djmkg.v52.i2.p100$\underline{104}$ 